\title{
Quantifying rates of dome-and-keel formation in the Barberton granitoid-greenstone belt, South Africa
}

\author{
Cristiano Lana ${ }^{\mathrm{a}, *}$, Eric Tohver $^{\mathrm{b}}$, Peter Cawood ${ }^{\mathrm{b}}$ \\ a Department of Geology, Geography and Environmental Studies, Stellenbosch University, Cnr Ryneveld and Merriman Streets, \\ Geology Building, Private Bag XI, Matieland 7602, Stellenbosch, WC, South Africa \\ b School of Earth and Geographical Sciences, University of Western Australia, 35 Stirling Hwy, Crawley, WA 6009, Australia
}

\section{A R T I C L E I N F O}

\section{Article history:}

Received 24 October 2008

Received in revised form

20 November 2009

Accepted 3 December 2009

\section{Keywords:}

Dome-and-keel

Barberton

Archean tectonics

Greenstone belt

Core-complex

\begin{abstract}
A B S T R A C T
The Barberton granitoid-greenstone belt is a classic dome-and-keel province, characterized by kilometerscale gneiss domes and elongate keels of largely folded supracrustal rocks. Combined U-Pb SHRIMP data and structural mapping demonstrate that the geometry of the Barberton belt reflects events that occurred over 30 million year interval, from ca. 3230 and 3203 Ma. Early deformation with NW-SE shortening in the upper crust was accompanied by emplacement of tonalite-trondhjemite-granodiorite TTG magmas at $3234 \pm 12$ and $3226 \pm 9$ Ma. Much of the structural grain of the greenstone belt relates to a long episode of post-orogenic extension, with NE-directed extension in the lower crust leading to exhumation of high-grade gneisses in the southern Barberton terrane. Advective heat transfer during emplacement of kilometer-scale (TTG) plutons around the margins of the greenstone belt facilitated the infolding of the relatively denser and colder greenstone sequence. The end of this tectonic cycle is punctuated by the emplacement of the undeformed, $3203 \pm 7$ Ma Dalmein pluton, which sharply truncates not only anticlines and synclines in the greenstone belt but also the dominant fabric in the high-grade gneisses.
\end{abstract} (c) 2009 Elsevier B.V. All rights reserved.

\section{Introduction}

The Archean Barberton granite-greenstone belt in the Mpumalanga Province of South Africa (Fig. 1) is a classic domeand-keel province that has featured in many debates over the role of vertical vs. horizontal tectonics in the Archean (Visser, 1956; Anhaeusser, 1969, 1984, 2001; Anhaeusser et al., 1981; De Wit et al., 1992; De Wit, 1998; Van Kranendonk et al., 2009). The geometry of the belt has been attributed to overturn of an inverted crustal density profile, in which vertical movement of the granitoid-gneiss domes was triggered primarily by magmatic processes in the midto upper-crusts (Viljoen and Viljoen, 1969; Anhaeusser et al., 1981; Jackson and Robertson, 1983; Van Kranendonk et al., 2009). This emphasis on vertical motion follows from the supposition that heat flows were 2-6 times higher in the Archean compared to modern environments, due to both the retention of primordial heat and higher radioactivity of ancient crust (e.g., Lambert, 1976). Other workers maintain that the dome-and-keel geometry reflects a more conventional tectonic regime dominated by horizontal motions during a major collisional event at 3230 Ma (e.g., De Wit et al., 1992; De Ronde and De Wit, 1994; Lowe, 1994; Schoene et al., 2008, 2009). In this interpretation, the steep structural fabrics

\footnotetext{
* Corresponding author. Tel.: +27 21808 4820; fax: +27 218083129 .

E-mail address: lana@sun.ac.za (C. Lana).
}

are the result of refolding of the greenstone sequences around rigid granitoid ramparts during progressive shortening (e.g., De Wit, 1983, 1998; De Wit et al., 1992; De Ronde and De Wit, 1994; Lowe, 1994, 1999; Lowe et al., 1999; De Ronde and Kamo, 2000).

A number of recent structural studies provide evidence that the granitoid-gneiss domes in the southern part of the belt were exhumed along a low-angle detachment surface (Figs. 1 and 2), following the main orogenic phase. These studies focus on the high- $P$ and low- $T$ metamorphic assemblages found in association with the granitoids, which suggest exhumation from depths of $30-50 \mathrm{~km}$. (Kisters et al., 2003; Diener et al., 2005; Moyen et al., 2006; Schoene et al., 2008; Lana et al., 2010). The relatively low strain intensities and low apparent geotherms $\left(<15-20^{\circ} \mathrm{C} / \mathrm{km}\right)$ recorded in the high-grade rocks in this portion of the belt point to the presence of cold and rigid continental blocks that could, at least temporarily, sustain significant crustal stacking and overthickening (e.g., Diener et al., 2005; Lana et al., 2010). However, while the new kinematic and metamorphic data from the Barberton belt are consistent with a core-complex scenario, geochronological constraints to illustrate the correct sequence of events are lacking. Consequently, the processes that shaped the geometry of the granitoid-greenstone belt have not been integrated with an accurate chronology of events.

This study presents new SHRIMP ages of key structural/ magmatic events that elucidate the formation of the dome-andkeel geometry in the Barberton belt. The new dataset provides 


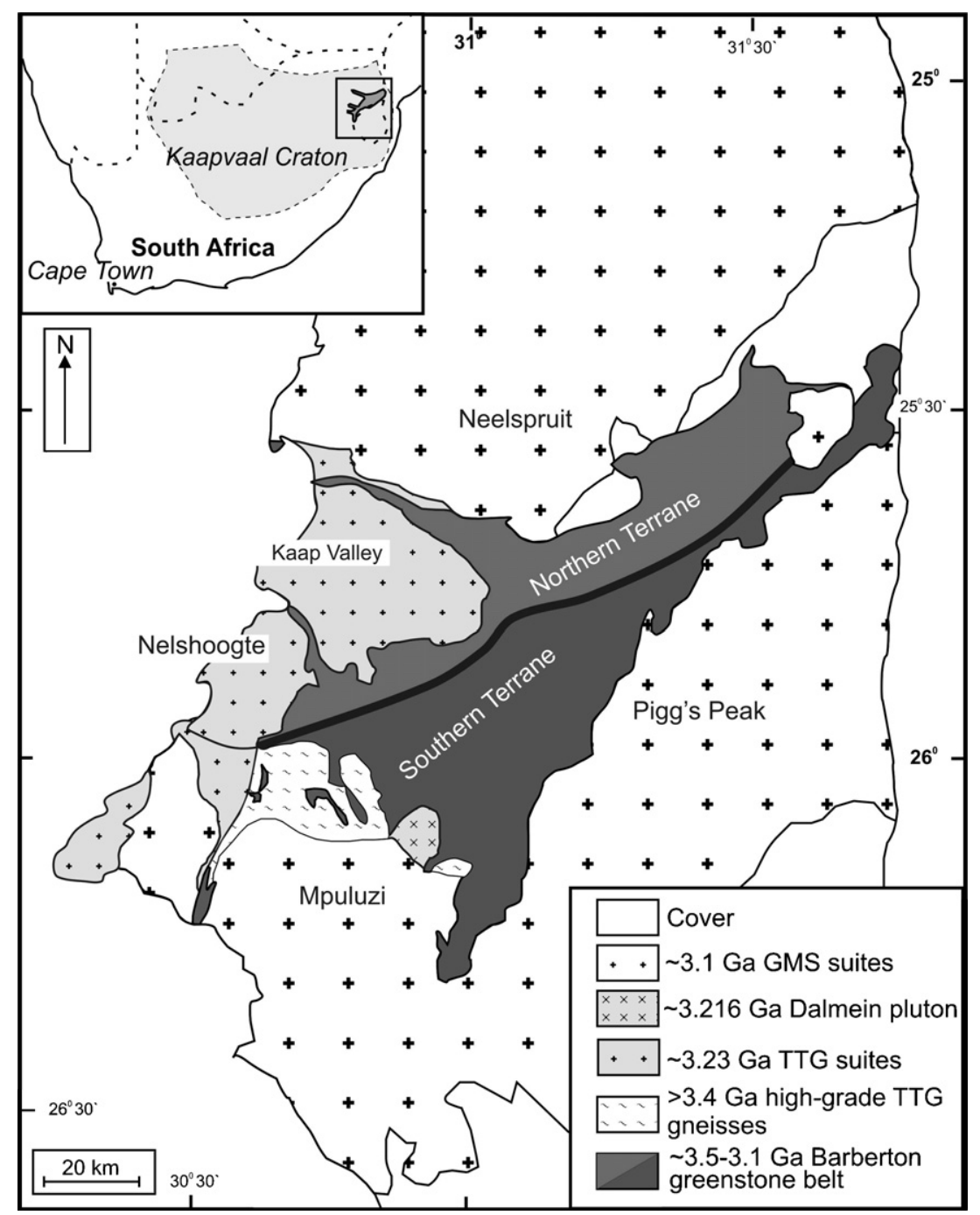

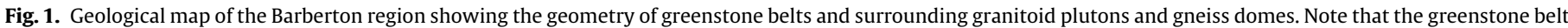
is subdivided into a northern and southern terrane.

important time constraints on the intrusive relationships between the gneisses and granitoids that were emplaced during the postcollisional phase. The timespan derived from our new data is consistent with contemporaneous exhumation of the high-grade gneisses and infolding of the greenstone supracrustal rocks. Integrating this new data with existing thermochronological constraints demonstrates that much of the dome-and-keel geometry is caused by sequential exhumation and related magmatism following the ca. $3230 \mathrm{Ma}$ assembly of the Barberton belt.

\section{Regional geology}

The ancient crust within the Barberton granitoid-greenstone belt records magmatic, metamorphic and structural events ranging from 3550 to $3100 \mathrm{Ma}$ (Armstrong et al., 1990; Kroner et al., 1989; Kröner et al., 1991, 1996; Kamo and Davis, 1994). Elongate keels of supracrustal rocks and broad, kilometer-scale granitoid-gneiss domes characterize much of the Barberton geology (Fig. 1) (Viljoen and Viljoen, 1969; Anhaeusser et al., 1981; Jackson and Robertson, 1983). Early studies focussed on the main lithostratigraphic groups of the low-grade metamorphic rocks in the greenstone belt (Viljoen and Viljoen, 1969; Anhaeusser, 1969), proposing a largely intact and structurally uninterrupted stratigraphy that is subdivided into (bottom to top): (1) mafic and ultramafic volcanic sequence of the Onverwacht Group, (2) sedimentary, volcanic and volcaniclastic rocks of the Fig Tree Group, and (3) predominantly coarse-grained clastic sedimentary rocks of the Moodies Group.

The original "layer cake" model with an uninterrupted stratigraphy for the Barberton greenstone belt was subsequently challenged by geochronological studies of $\mathrm{U}-\mathrm{Pb}$ in zircon (e.g., Armstrong et al., 1990; Kröner et al., 1991). It is now known that compositionally similar units and formations cannot be correlated throughout the belt (Armstrong et al., 1990; Kröner et al., 1991; Kohler and Anhaeusser, 2002; Byerly et al., 1996). For example, the metavolcanic rocks of the Onverwacht Group, exposed along the northern flank of the greenstone belt, were shown to be some $200 \mathrm{Ma}$ younger than similar rocks in the southern type locality (Byerly et al., 1996). Rock units thought to be characteristic of the lowermost Theespruit Formation at the base of the greenstone belt in the south, were shown to be almost 300 Ma younger in the north (e.g., Kohler and Anhaeusser, 2002). The geochronological differences, together with abrupt facies changes recorded in both the Onverwacht Group and Fig Tree Group, have since been interpreted as indicating the presence of two distinct island arcs, namely, a northern terrane and southern terrane (Fig. 1) (De Wit et al., 1992; De Ronde and De Wit, 1994; De Ronde and Kamo, 2000).

While an early D1 deformation phase is preserved in the lower, ca. 3400 Ma stratigraphic units of the Onverwacht Group (Fig. 3), a common metamorphic history beginning at ca. $3230 \mathrm{Ma}$ for both the northern and southern terranes has given rise to a collisional 


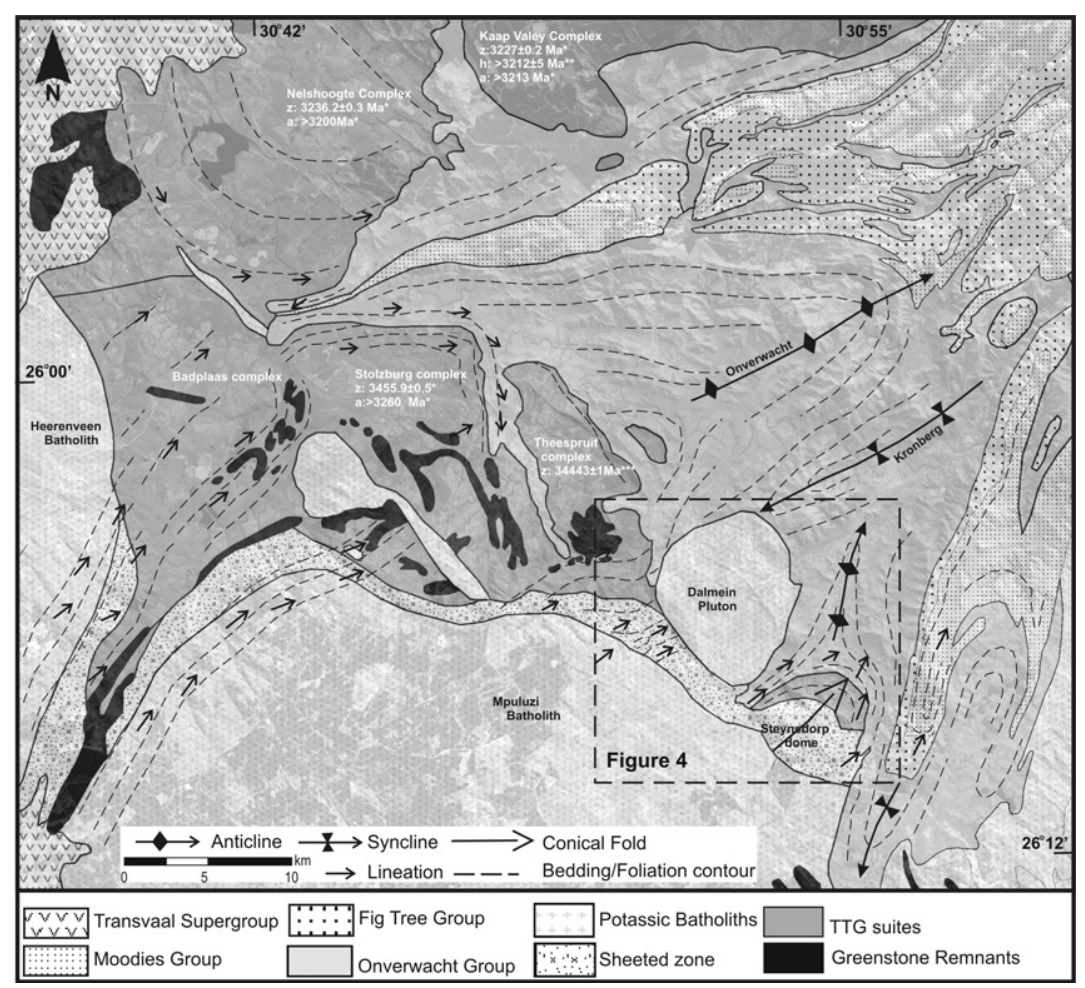

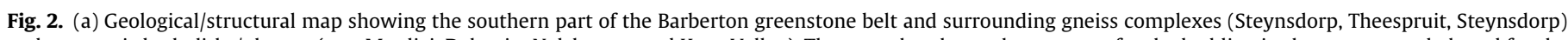

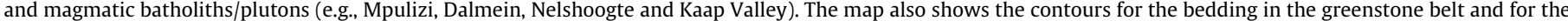

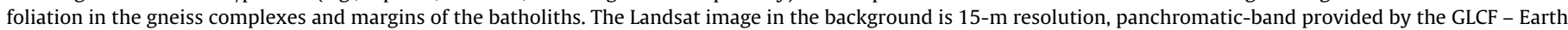

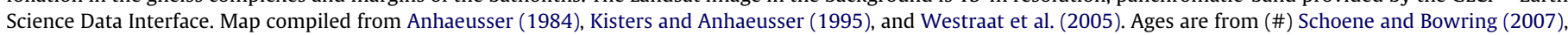
$\left({ }^{*}\right)$ Schoene et al. (2008), (**) Layer et al. $(1992,1998)$ and $\left({ }^{* * *}\right)$ Kamo and Davis (1994).

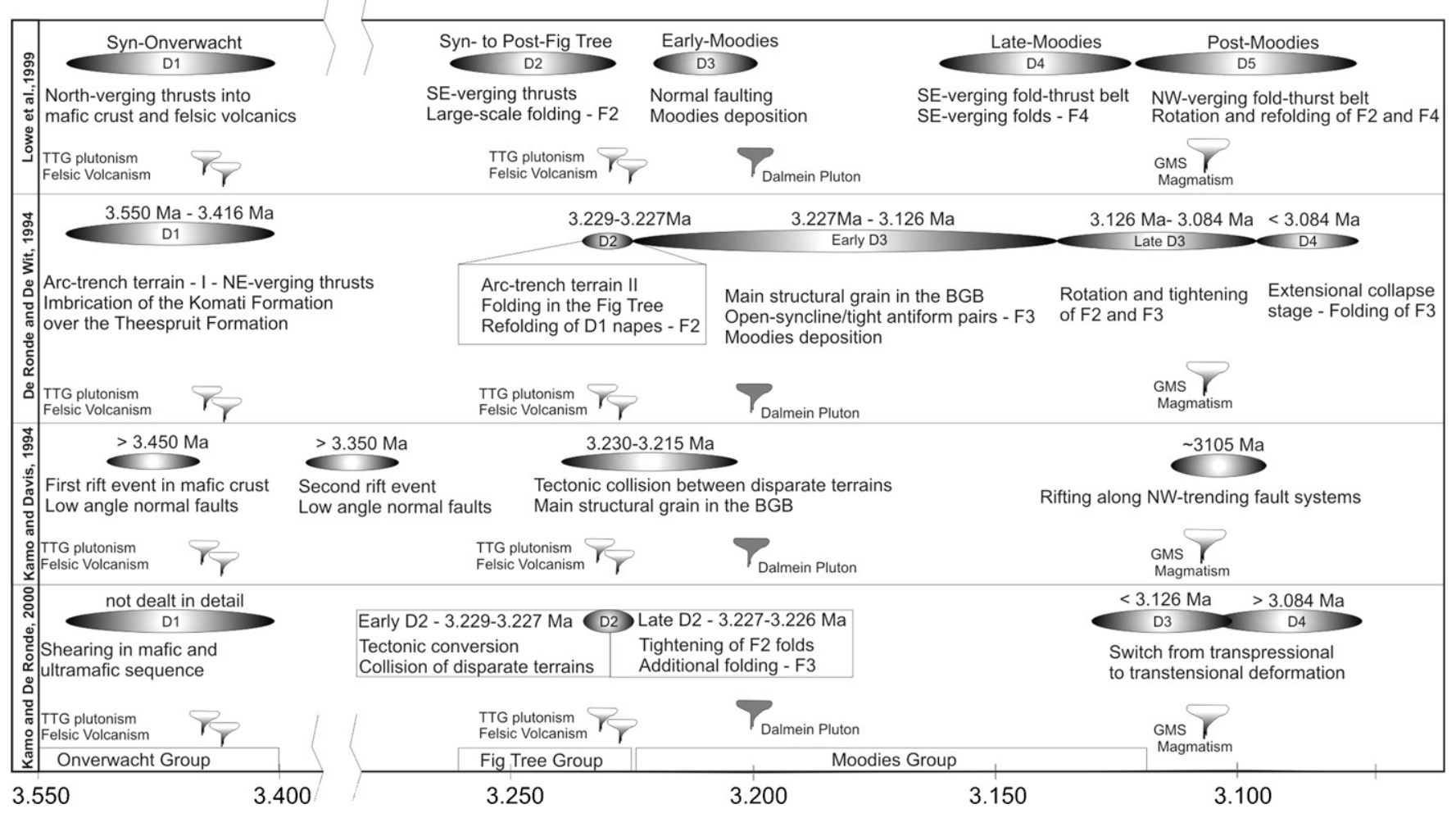

Fig. 3. Chart diagram illustrating the main tectonic models proposed for the evolution of the Barberton region. 
interpretation for the Barberton belt. The main collisional phase (D2) was accompanied by the emplacement of TTG batholiths (e.g., Kaap Valley pluton; Fig. 2) and regional metamorphism in the Barberton region (Armstrong et al., 1990; Kröner et al., 1991; Kamo and Davis, 1994; Dziggel et al., 2002, 2005, 2006; Kisters et al., 2003; Diener et al., 2005). Most workers (e.g., Fig. 3) attribute the dominant regional strain to this event, although the details remain controversial; e.g., the exact number of distinct terranes, and the location of suture zones (see summary in Lowe and Byerly, 2007). This D2 collision also marks a significant change in the depositional style of the supracrustal rocks, from turbiditic sedimentation of the Fig Tree Group to coarse, molassic sediments that comprise the Moodies Group (Fig. 3) (Eriksson, 1979; Lamb, 1987; Heubeck and Lowe, 1994).

The evolution of the belt in the aftermath of the collision remains less clear, with much disagreement hinging on the absolute ages of various post-collisional (D3) features. In identifying the inflection point between compressive tectonics and extension, some workers favor an extremely rapid period of collision and compression (ca. $15 \mathrm{Ma}$ - Kamo and Davis, 1994; or $3 \mathrm{Ma}$ - De Ronde and Kamo, 2000), while others propose a $>100 \mathrm{Ma}$ transitional period (e.g., De Ronde and De Wit, 1994; Schoene et al., 2008) (Fig. 3). The age of the post-orogenic plutons such as the Dalmein intrusion (in the southern part of the Barberton greenstone bet: Fig. 2) is critical to resolving this question, as it clearly post-dates the main phase of compressional tectonics and was emplaced at relatively shallow, upper crustal conditions in the wake of regional metamorphism and deformation. The final episode of magmatism in the region is the intrusion of granodiorite-monzogranite-syenite (GMS) batholiths such as the Mpuluzi batholith, to the south of the Dalmein pluton, at ca. $3100 \mathrm{Ma}$ (Fig. 2) (Jackson and Robertson, 1983; Westraat et al., 2005; Belcher and Kisters, 2006; Schoene et al., 2008). This plutonism accompanied the formation of intracratonic basins in the central parts of the Kaapvaal Craton (Fig. 3) (De Ronde and De Wit, 1994; De Ronde and Kamo, 2000; Schoene et al., 2008).

The question we address in this contribution is whether the dome-and-keel architecture of the granitoid-greenstone belt (Fig. 3) was achieved during continuous, long-lived deformation, possibly diachronous throughout the belt (D2/D3, De Ronde and De Wit, 1994; D3-D4 Lowe et al., 1999) or whether the seemingly coaxial D2 and D3 events form distinct episodes during which older pre-existing structures were reactivated (e.g., Kamo and Davis, 1994; De Ronde and Kamo, 2000).

\section{Field relationships}

\subsection{Lithologies and contact relationships}

Granitoid rocks exposed between the Mpuluzi and Dalmein plutons (Fig. 4a and b) comprise tonalitic, trondhjemitic and granodioritic (TTG) gneisses that are intruded by multiple horizontal sheets and vertical dykes of potassic granitoids (Anhaeusser et al., 1981; Robb et al., 1983; Westraat et al., 2005). Outcrops immediately to the south of the Theespruit gneiss and Dalmein pluton expose remnants of a strongly foliated trondhjemitic gneiss, which has been intruded to the south by a banded granodiorite gneiss, and subsequently by potassic leucogranite sheets (Figs. 4 and 5). The trondhjemitic gneiss, hereafter referred to the Southern Theespruit Gneiss (Fig. 5a), is a medium-grained grey gneiss consisting dominantly of quartz, plagioclase, orthoclase, biotite and hornblende. The foliation (or gneissosity) is mainly defined by hornblende and biotite clots that wrap around recrystallized K-feldspar, quartz and

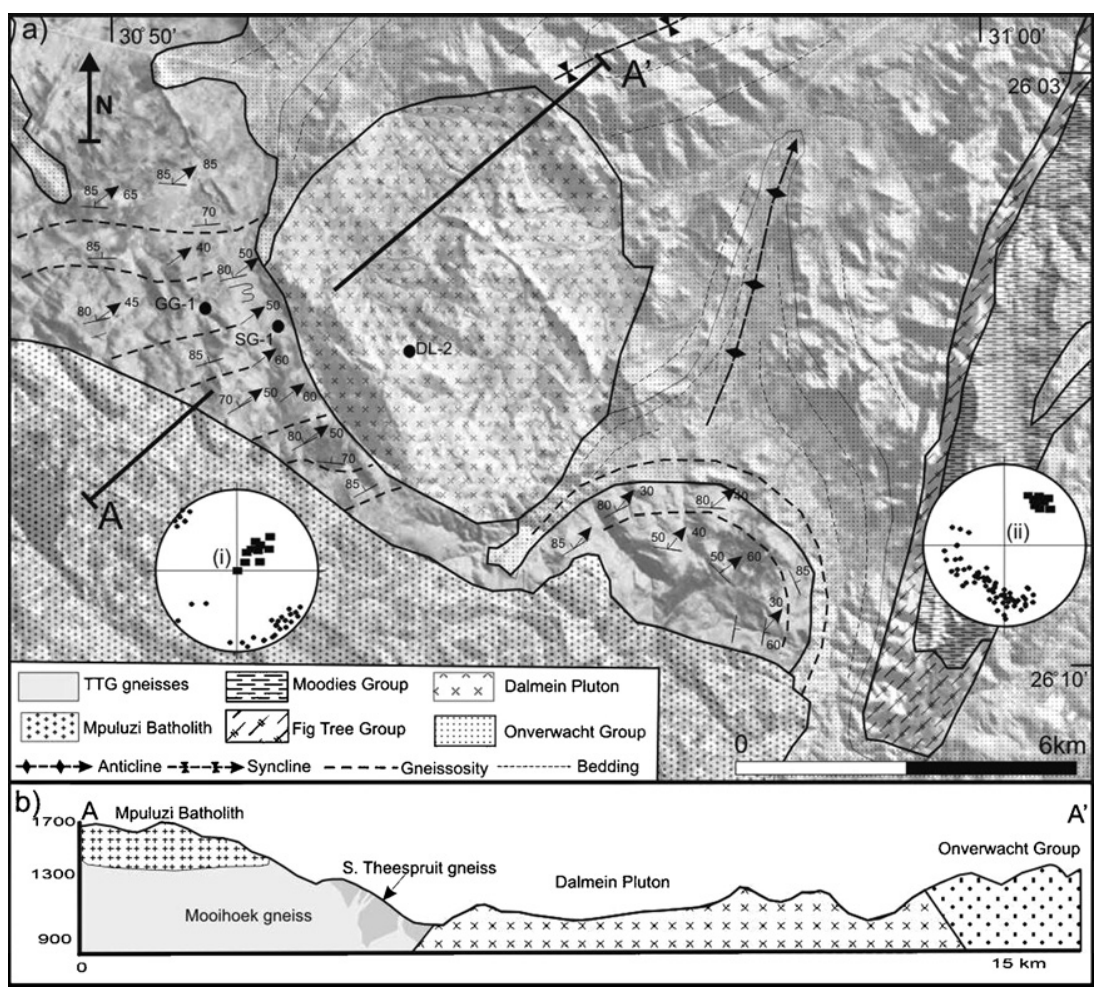

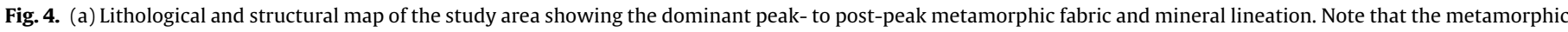

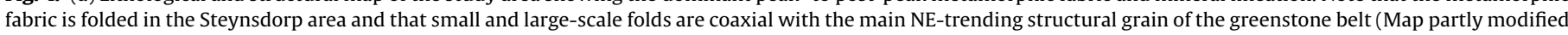

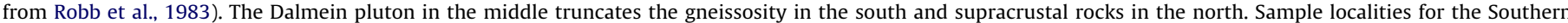

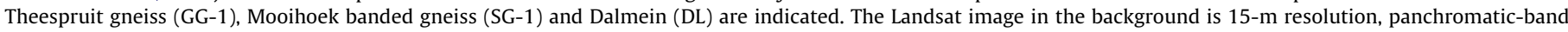

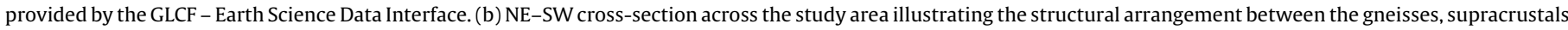
and younger intrusives. 

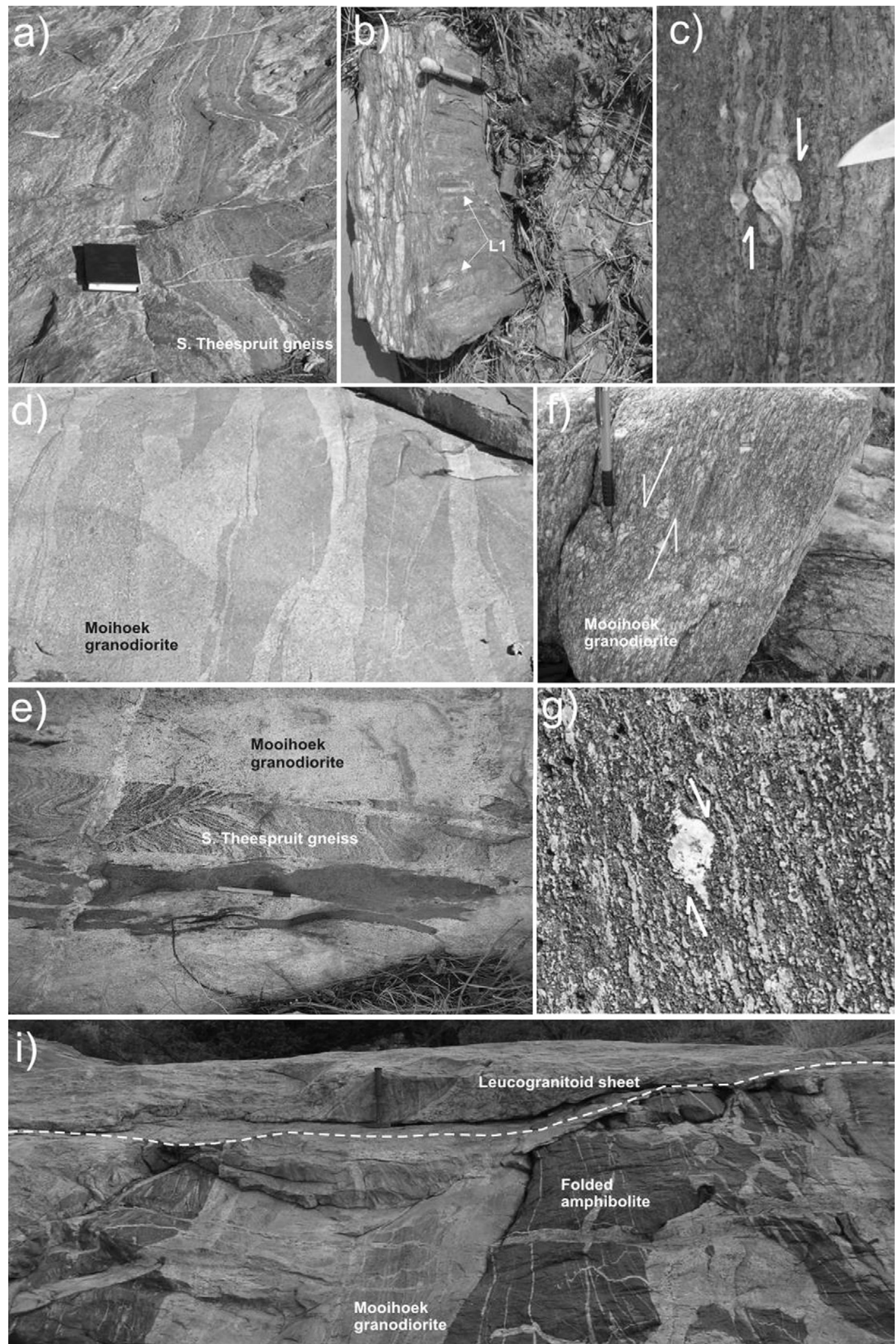

Fig. 5. (a) Strongly foliated Southern Theespruit Gneiss. Note the solid-state gneissosity defined by hornblende and biotite minerals. (b) Layer-parallel boudinage of millimeterwide felsic bands in the Southern Theespruit gneiss. (c) Rotated plagioclase along the fabric in the Southern Theespruit gneiss. (d) Banded Mooihoek gneiss showing alternating plagioclase-rich and biotite-rich bands. Both bands record a pervasive solid-state fabric defined by recrystallized quartz and feldspar and aligned biotite. (e) Xenoliths of the strongly foliated Southern Theespruit Gneiss in the Mooihoek gneiss. Note the presence of a segmented mafic layer in contact with Southern Theespruit Gneiss. (f) Solid-state fabric in the plagioclase-rich bands in the sheeted granitoid zone. (g) Rotated plagioclase along the fabric in the Mooihoek gneiss. (h) Complex contact/intrusive relationships between the banded (and foliated) gneisses, amphibolites (remnants of greenstones) and leucogranite sheets. There is often a color contrast between the white plagioclase-rich banding in the granodiorites and the rather pink K-feldspar-rich leucogranite sheets. Dashed white line marks the lower contact of the leucogranite sheet. 
plagioclase. Locally, the gneisses show a compositional layering defined by alternating decimeter-wide grey, granodioritic bands and white felsic bands. The feldspar-rich bands record a strong NEplunging lineation (Fig. 4a, inset $\mathrm{i}$ ) defined by elongate aggregates of quartz and feldspar. In places, the felsic bands record layer-parallel extension and boudinage, with stretching parallel to the mineral lineation (Fig. 5b). The grain shape preferred orientation of these feldspar-quartz aggregates defines a pervasive S/L fabric.

The banded granodioritic gneiss, the Mooihoek banded granodiorite, intrudes parallel to, and locally crosscuts, the main foliation of the Southern Theespruit gneiss (Fig. 5d). In many places, xenoliths of the older Southern Theespruit gneiss are exposed (Fig. 5e) within the younger Mooihoek Gneiss intrusion. The compositional layering of the Mooihoek granodiorite is mainly defined by centimeter-scale felsic layers that alternate with bands of biotite and hornblende (Fig. 5d). The plagioclase-rich bands are characterized by strongly oriented, euhedral to subhedral K-feldspar megacrysts that reach lengths of up to $5 \mathrm{~cm}$, evidence of an early magmatic fabric. This fabric has been partially overprinted, with fine- and coarse-grained granodioritic phases showing solid-state fabrics including asymmetric porphyroblasts of plagioclase (Figs. $5 \mathrm{f}$ and $g$ ). The geometry of these asymmetric fabrics is consistent with a normal sense of shear with greenstone material down and granitoid rocks up.

Supracrustal remnants are relatively rare and mainly occur as isolated, meter- to several decameter-large, mostly amphibolitefacies mafic layers that are transposed along the main fabric (Fig. 5i). These supracrustal segments are intensely foliated, although primary intrusive relationships can still be discerned in the form of foliation, bedding parallel, and variably transposed trondhjemitic apophyses in the basal 10-15 m of the Theespruit Formation.

To the north, amphibolite-facies gneisses are cross cut by the Dalmein Pluton - a 5-km-wide homogenous, granodioritic pluton that also truncates the metavolcanic and sedimentary rocks of the greenstone belt. The granodiorite is characterized by por- phyritic textures with randomly oriented K-feldspar megacrysts, zoned plagioclase, and quartz. Biotite and epidote are common in hand-specimen. Xenoliths are common throughout the pluton, with massive blocks of the greenschist facies metavolcanic and felsic schists from the Theespruit Formation evident (Fig. 6a and b), especially along the eastern and western margins of the pluton (cf. Robb et al., 1983). In the southern portions of the Dalmein pluton, these amphibolite-facies xenoliths take the form of folded and boudinaged granitic bands that alternate with the amphibolites (Fig. 6c).

\subsection{Fabric development}

The metamorphic foliation and compositional layering trend predominantly NE-SW, but with an E-W trend in some isolated locations (Fig. 4a). This fabric is the lateral extension of the amphibolite-facies foliation that wraps around the Theespruit, Steynsdorp and Stolzburg complexes (Kisters et al., 2003; Diener et al., 2005; Schoene et al., 2008; Lana et al., 2010) (Fig. 4a). At a larger scale, the strain fabric contains the fold axes of the kilometerscale Kromberg antiformal syncline (De Ronde and De Wit, 1994) and Steynsdorp anticline (Kisters and Anhaeusser, 1995) (Fig. 2). Both of these regional features contain smaller, parasitic folds with wavelengths of $1-100 \mathrm{~m}$. Many of these folds have tight, isoclinal geometries with fold axes that plunge to the NE at shallow to moderate angles (Fig. 5i).

A number of vertical shear zones are found, also with NE-SW trends. Several kinematic indicators; e.g., asymmetric folds, S$\mathrm{C}$ fabrics and mantled plagioclase (Fig. 5c), reveal a consistent greenstone-rocks-down/granitoid-up sense of motion (Fig. 4a, inset ii) (cf. Kisters et al., 2003; Diener et al., 2005; Schoene et al., 2008; Lana et al., 2010). A NE-plunging lineation (L1) defined by aligned biotite and hornblende grains and recrystallized feldspar and quartz grains is parallel to the trend and plunge of fold axes. The plastic deformation of the quartzofeldspathic material in these
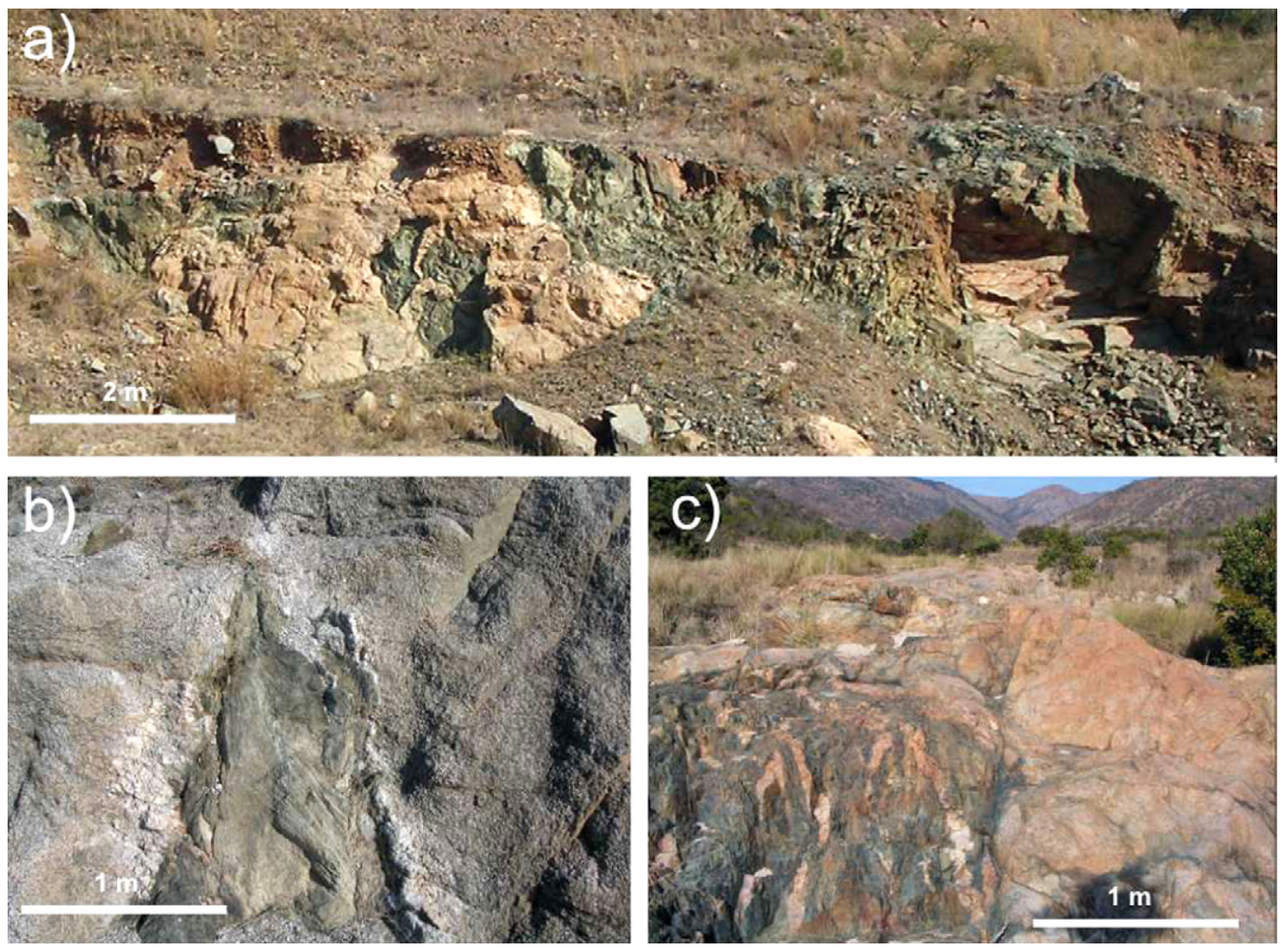

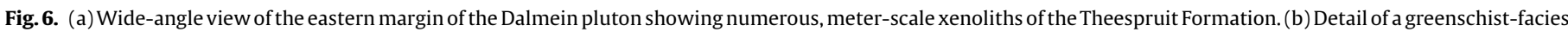
xenoliths of the Theespruit formation. (c) Detail of a strongly layered, amphibolite-facies xenoliths in the southern margin of the pluton. 
Table 1

SHRIMP data for the Southern Theespruit Gneiss, Moihoek Gneiss and Dalmein.

\begin{tabular}{|c|c|c|c|c|c|c|c|c|c|c|c|c|c|c|c|c|c|}
\hline$\#$ & Point Anlayses & comm 206 & ppm U & ppm Th & $232 \mathrm{Th} / 238 \mathrm{U}$ & $207 / 206$ & $1 \sigma^{\mathrm{a}}$ & $207 / 235$ & $1 \sigma^{\mathrm{a}}$ & $206 / 238$ & $1 \sigma^{\mathrm{a}}$ & Rho & $206 \mathrm{~Pb} / 238 \mathrm{U}$ & $1 \sigma^{\mathrm{b}}$ & $207 \mathrm{~Pb} / 206 \mathrm{~Pb}$ & $1 \sigma^{\mathrm{b}}$ & Disc. $^{c}$ \\
\hline \multicolumn{18}{|c|}{ Southern Theespruit Gneiss GG1 } \\
\hline 20 & CL2-GG2-6 & 0.01 & 162 & 50 & 0.32 & 0.29 & 0.0006 & 27.30 & 2.6122 & 0.68 & 2.6042 & 1.00 & 3330 & 68 & 3432 & 3 & 0.03 \\
\hline 19 & GG02-CL2-103 & 0.29 & 215 & 38 & 0.18 & 0.26 & 0.0008 & 21.87 & 1.6570 & 0.62 & 1.6252 & 0.98 & 3115 & 40 & 3218 & 5 & 0.03 \\
\hline 18 & GG02-CL2-109 & 0.03 & 346 & 244 & 0.73 & 0.29 & 0.0013 & 25.85 & 1.5840 & 0.64 & 1.5210 & 0.96 & 3204 & 38 & 3424 & 7 & 0.07 \\
\hline 17 & GG1-CL2-4 & 0.04 & 383 & 274 & 0.74 & 0.30 & 0.0006 & 26.62 & 1.3912 & 0.64 & 1.3789 & 0.99 & 3197 & 35 & 3474 & 3 & 0.09 \\
\hline 16 & GG1-CL2-5 & 0.07 & 329 & 59 & 0.19 & 0.25 & 0.0006 & 19.02 & 1.5160 & 0.55 & 1.4988 & 0.99 & 2832 & 34 & 3186 & 4 & 0.13 \\
\hline 15 & GG02-CL2-103.1 & 1.32 & 358 & 38 & 0.11 & 0.25 & 0.0012 & 18.64 & 1.4790 & 0.55 & 1.3973 & 0.94 & 2809 & 32 & 3169 & 8 & 0.13 \\
\hline 14 & CL2-GG2-4 & 0.05 & 253 & 11 & 0.05 & 0.25 & 0.0007 & 18.81 & 2.8503 & 0.55 & 2.8368 & 1.00 & 2812 & 65 & 3181 & 4 & 0.13 \\
\hline 13 & CL2-GG2-2 & 0.07 & 465 & 341 & 0.76 & 0.30 & 0.0005 & 25.18 & 2.5883 & 0.61 & 2.5835 & 1.00 & 3065 & 63 & 3470 & 2 & 0.13 \\
\hline 12 & GG02-CL2-101 & 0.06 & 408 & 17 & 0.04 & 0.25 & 0.0009 & 17.93 & 1.5824 & 0.53 & 1.5389 & 0.97 & 2725 & 34 & 3167 & 6 & 0.16 \\
\hline 11 & CL2-GG2-5 & 0.08 & 1118 & 6 & 0.01 & 0.21 & 0.0016 & 12.37 & 3.2152 & 0.43 & 3.1177 & 0.97 & 2309 & 61 & 2892 & 13 & 0.25 \\
\hline 10 & GG02-CL2-105 & 0.19 & 546 & 66 & 0.13 & 0.25 & 0.0010 & 16.96 & 1.5996 & 0.49 & 1.5512 & 0.97 & 2551 & 33 & 3206 & 6 & 0.26 \\
\hline 9 & GG02-CL2-6.1 & 0.07 & 494 & 4 & 0.01 & 0.24 & 0.0005 & 14.86 & 1.4780 & 0.45 & 1.4604 & 0.99 & 2417 & 29 & 3099 & 4 & 0.28 \\
\hline 8 & GG1-CL2-2 & 4.72 & 881 & 794 & 0.93 & 0.22 & 0.0029 & 12.26 & 1.9754 & 0.41 & 1.4399 & 0.73 & 2216 & 27 & 2957 & 22 & 0.33 \\
\hline 7 & GG02-CL2-110 & 0.13 & 835 & 492 & 0.61 & 0.26 & 0.0007 & 15.61 & 1.4128 & 0.43 & 1.3870 & 0.98 & 2315 & 27 & 3259 & 4 & 0.41 \\
\hline 6 & GG02-CL2-102 & 0.04 & 353 & 339 & 0.99 & 0.24 & 0.0011 & 13.37 & 1.5757 & 0.40 & 1.5133 & 0.96 & 2164 & 28 & 3141 & 7 & 0.45 \\
\hline 5 & GG1-CL2-1 & 0.25 & 889 & 151 & 0.18 & 0.21 & 0.0004 & 10.09 & 1.5150 & 0.35 & 1.4997 & 0.99 & 1942 & 25 & 2892 & 3 & 0.49 \\
\hline 4 & GG1-CL2-3 & 2.54 & 850 & 116 & 0.14 & 0.22 & 0.0040 & 11.18 & 2.2383 & 0.36 & 1.3736 & 0.61 & 1991 & 24 & 3010 & 28 & 0.51 \\
\hline 3 & CL2-GG2-3 & 0.13 & 847 & 563 & 0.69 & 0.21 & 0.0016 & 8.50 & 2.6862 & 0.29 & 2.5839 & 0.96 & 1636 & 37 & 2932 & 12 & 0.79 \\
\hline 2 & CL2-GG2-1 & 4.25 & 919 & 434 & 0.49 & 0.21 & 0.0021 & 5.18 & 2.8405 & 0.18 & 2.6441 & 0.93 & 1076 & 26 & 2881 & 17 & 1.68 \\
\hline 1 & GG02-CL2-104 & 0.18 & 954 & 20 & 0.02 & 0.17 & 0.0007 & 3.33 & 1.4731 & 0.14 & 1.4185 & 0.96 & 856 & 11 & 2555 & 7 & 1.98 \\
\hline \multicolumn{18}{|c|}{ Moihoek Gneiss SG-1 } \\
\hline 1 & SG11-CL1-103 & 5.38 & 198 & 43 & 0.22 & 0.24 & 1.9907 & 7.01 & 2.6650 & 0.21 & 1.7719 & 0.66 & 1255 & 20 & 3096 & 32 & 1.47 \\
\hline 2 & CL1-SG01-4 & 2.62 & 295 & 109 & 0.38 & 0.25 & 0.7307 & 17.54 & 2.7003 & 0.50 & 2.5995 & 0.96 & 2629 & 56 & 3201 & 12 & 0.22 \\
\hline 3 & CL1-SG01-2 & 0.48 & 386 & 228 & 0.61 & 0.25 & 0.2398 & 18.09 & 2.6008 & 0.52 & 2.5897 & 1.00 & 2714 & 57 & 3188 & 4 & 0.17 \\
\hline 4 & CL1-SG01-1 & 0.54 & 138 & 62 & 0.46 & 0.25 & 0.3423 & 18.79 & 2.7789 & 0.54 & 2.7578 & 0.99 & 2763 & 62 & 3214 & 5 & 0.16 \\
\hline 5 & SG11-CL1-101 & 0.04 & 523 & 458 & 0.91 & 0.25 & 0.3645 & 18.60 & 1.4343 & 0.54 & 1.3872 & 0.97 & 2795 & 31 & 3176 & 6 & 0.14 \\
\hline 6 & SG11-CL1-104 & 0.73 & 94 & 110 & 1.20 & 0.25 & 0.6492 & 19.27 & 1.6643 & 0.55 & 1.5324 & 0.92 & 2832 & 35 & 3206 & 10 & 0.13 \\
\hline 7 & CL1-SG01-3 & 1.15 & 176 & 100 & 0.59 & 0.25 & 0.4143 & 19.55 & 2.6401 & 0.56 & 2.6074 & 0.99 & 2866 & 60 & 3206 & 7 & 0.12 \\
\hline 8 & SG1-CL1-107 & 0.63 & 253 & 161 & 0.66 & 0.25 & 0.3418 & 19.97 & 1.4537 & 0.57 & 1.4129 & 0.97 & 2917 & 33 & 3204 & 5 & 0.10 \\
\hline 9 & SG1-CL1-106 & 0.01 & 237 & 123 & 0.54 & 0.26 & 0.2571 & 21.50 & 1.4346 & 0.61 & 1.4114 & 0.98 & 3067 & 34 & 3221 & 4 & 0.05 \\
\hline 10 & SG1-CL1-105 & 0.03 & 204 & 106 & 0.54 & 0.26 & 0.2687 & 21.65 & 1.4516 & 0.61 & 1.4265 & 0.98 & 3084 & 35 & 3222 & 4 & 0.04 \\
\hline 11 & CL1-SG01-6 & 0.08 & 656 & 568 & 0.01 & 0.24 & 0.3254 & 20.30 & 2.6641 & 0.60 & 2.6442 & 0.99 & 3050 & 64 & 3142 & 5 & 0.03 \\
\hline \multicolumn{18}{|c|}{ Dalmein Pluton DL } \\
\hline 1 & CL2-DL1-1 & 2.16 & 764 & 603 & 0.82 & 0.21 & 0.4403 & 6.63 & 2.7127 & 0.24 & 2.6028 & 0.96 & 1405 & 33 & 2805 & 13 & 1.00 \\
\hline 2 & DL2-24B & 0.17 & 694 & 212 & 0.32 & 0.21 & 0.3478 & 8.49 & 2.0364 & 0.29 & 2.0065 & 0.99 & 1630 & 29 & 2937 & 6 & 0.80 \\
\hline 3 & DL2-31B & 0.21 & 713 & 549 & 0.80 & 0.22 & 0.5507 & 10.41 & 2.3821 & 0.34 & 2.3176 & 0.97 & 1907 & 38 & 2975 & 9 & 0.56 \\
\hline 4 & DL1-CL2-104.1 & 1.59 & 661 & 275 & 0.43 & 0.21 & 0.5446 & 10.88 & 1.5127 & 0.37 & 1.4113 & 0.93 & 2028 & 25 & 2933 & 9 & 0.45 \\
\hline 5 & DL2-15B & 0.06 & 542 & 159 & 0.30 & 0.23 & 0.2776 & 13.35 & 1.9227 & 0.42 & 1.9025 & 0.99 & 2239 & 36 & 3074 & 4 & 0.37 \\
\hline 6 & DL2-33B & 0.18 & 527 & 270 & 0.53 & 0.24 & 0.2702 & 19.73 & 2.7634 & 0.60 & 2.7502 & 1.00 & 3012 & 66 & 3122 & 4 & 0.37 \\
\hline 7 & DL2-22B & 0.05 & 587 & 258 & 0.45 & 0.24 & 0.2592 & 14.10 & 1.8027 & 0.43 & 1.7840 & 0.99 & 2328 & 35 & 3087 & 4 & 0.33 \\
\hline 8 & CL2-DL1-8 & 0.12 & 613 & 260 & 0.44 & 0.22 & 0.1602 & 13.25 & 2.6814 & 0.43 & 2.6766 & 1.00 & 2304 & 52 & 3007 & 3 & 0.31 \\
\hline 9 & DL1-CL2-6.1 & 0.64 & 398 & 111 & 0.29 & 0.23 & 0.3606 & 13.82 & 1.4302 & 0.44 & 1.3840 & 0.97 & 2350 & 27 & 3037 & 6 & 0.29 \\
\hline 10 & DL1-CL2-103 & 0.32 & 574 & 296 & 0.53 & 0.24 & 0.2530 & 15.06 & 1.5639 & 0.46 & 1.5433 & 0.99 & 2434 & 31 & 3108 & 4 & 0.28 \\
\hline 11 & DL2B-8 & 0.22 & 271 & 181 & 0.69 & 0.24 & 0.4094 & 16.69 & 2.0389 & 0.50 & 1.9974 & 0.98 & 2604 & 43 & 3141 & 7 & 0.21 \\
\hline 12 & DL1-CL2-105 & 0.40 & 483 & 188 & 0.40 & 0.24 & 0.3232 & 16.94 & 1.4220 & 0.51 & 1.3848 & 0.97 & 2647 & 30 & 3133 & 5 & 0.18 \\
\hline 13 & CL2-DL1-5 & 0.12 & 438 & 169 & 0.40 & 0.24 & 0.1620 & 17.74 & 2.6166 & 0.53 & 2.6116 & 1.00 & 2745 & 58 & 3136 & 3 & 0.14 \\
\hline 14 & DL2-23B & 0.06 & 298 & 317 & 1.10 & 0.25 & 0.3260 & 18.85 & 2.5185 & 0.55 & 2.4973 & 0.99 & 2831 & 57 & 3172 & 5 & 0.12 \\
\hline 15 & DL1-CL2-108 & 0.15 & 447 & 215 & 0.50 & 0.24 & 0.2319 & 18.22 & 1.4074 & 0.55 & 1.3882 & 0.99 & 2818 & 32 & 3127 & 4 & 0.11 \\
\hline 16 & DL2B-7 & 0.17 & 203 & 144 & 0.73 & 0.25 & 0.5082 & 18.93 & 2.4023 & 0.56 & 2.3480 & 0.98 & 2862 & 54 & 3157 & 8 & 0.10 \\
\hline 17 & DL2-13B & 0.01 & 383 & 568 & 1.53 & 0.25 & 0.2774 & 19.63 & 1.8095 & 0.57 & 1.7881 & 0.99 & 2900 & 42 & 3188 & 4 & 0.10 \\
\hline 18 & DL2-5.1B & 0.06 & 463 & 278 & 0.62 & 0.25 & 0.3171 & 19.44 & 1.8276 & 0.57 & 1.7998 & 0.98 & 2908 & 42 & 3168 & 5 & 0.09 \\
\hline 19 & DL2-35.1B & 0.05 & 443 & 143 & 0.33 & 0.25 & 0.2749 & 19.69 & 1.8557 & 0.57 & 1.8352 & 0.99 & 2928 & 43 & 3175 & 4 & 0.08 \\
\hline
\end{tabular}




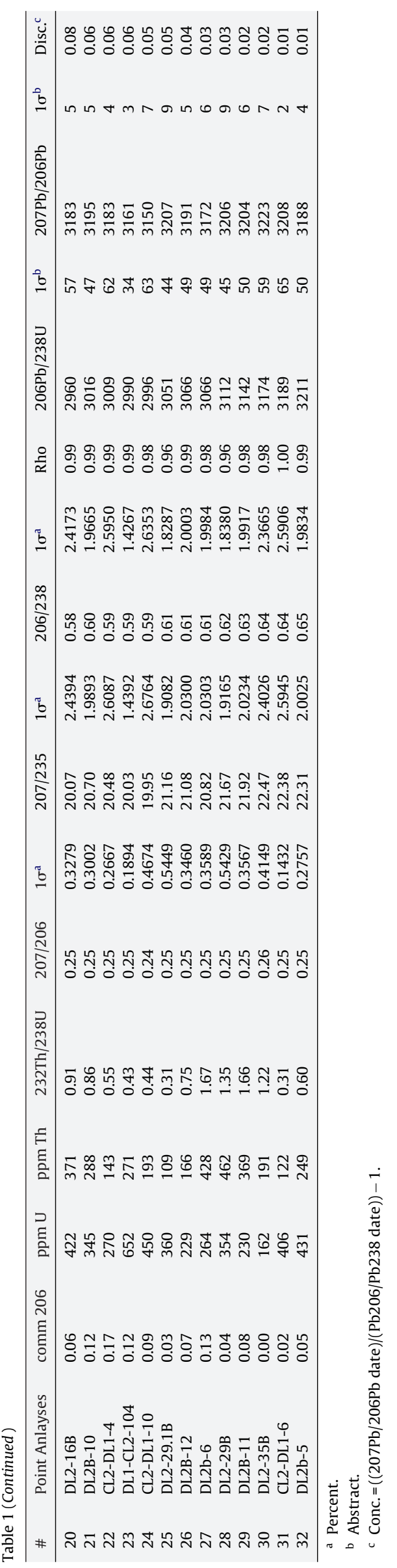

lineated aggregates indicates strain under peak amphibolite-facies conditions. Highly prolate aspect ratios (Fig. 5b) are consistent with stretching mineral lineation developed under constrictional strain. Significantly, this lineation is unidirectional, and has not been affected by subsequent folding events.

In summary, the main fabric forming event in the southern Barberton terrane occurred during exhumation of the highgrade gneisses domes (Steynsdorp, Stolzburg and Theespruit; Figs. 1 and 2a) and emplacement of numerous granodiorite-granite sheets. The intrusion of the Dalmein pluton occurred at a relatively shallow level, in the waning stages of exhumation. Later emplacement of leucogranites such as the Mpuluzi batholith reactivated pre-existing structures under low-grade conditions (e.g., Westraat et al., 2005; Belcher and Kisters, 2006; Schoene et al., 2008). In the following section, we provide new $\mathrm{U}-\mathrm{Pb}$ age data obtained from samples of the Southern Theespruit (GG-1) and Mooihoek gneisses (SG-1), and the Dalmein pluton (DL).

\section{Geochronology}

\subsection{Analytical techniques}

The U-Pb analyses were conducted using the WA Consortium SHRIMP II ion microprobe housed at Curtin University of Technology. Analytical procedures are described by Nelson (1997) and Williams (1998). Detailed cathodoluminescence images are shown in the online electronic Appendix (ES-1). Isotopic ratios were monitored with reference to Sri Lankan gem zircon standard BR266, with an age of $559.1 \mathrm{Ma}$, and $\mathrm{Pb} / \mathrm{U}$ ratios in the samples were corrected using the $\ln (\mathrm{Pb} / \mathrm{U}) / \ln (\mathrm{UO} / \mathrm{U})$ relationship as measured on zircons standard. All uncertainties in the calculated intercept or Concordia ages are reported at $95 \%$ confidence limits, unless stated otherwise. The results of the spot analyses are presented in Table 1.

\subsection{Southern Theespruit gneiss (GG-1)}

The granodioritic gneiss was collected $1.5 \mathrm{~km}$ south of the contact with the Theespruit pluton $\left(26^{\circ} 06^{\prime} 12^{\prime \prime} \mathrm{S}-30^{\circ} 51^{\prime} 07^{\prime \prime} \mathrm{E}\right)$ (Fig. 4a). The sample is marked by a strong solid-state foliation (Fig. 5a) defined by peak metamorphic biotite and hornblende and recrystallized plagioclase, K-feldspar, and quartz. Accessory minerals include titanite, apatite, magnetite and zircon. Zircons extracted from this sample vary from translucent to milky, with pink and brown colors. Most of them are clearly zoned, some of which contain cores and/or metamorphic rims (ES-1). Other grains were homogeneous and particularly bright under CL. We targeted the centers of both zoned and homogeneous grains.

All the ion microprobe data from this sample are plotted on the concordia diagram (Fig. 7a). Two distinct zircon populations are present based on age grouping, Th/U ratios, and, to some extent, zircon morphology. Four analyses from the cores of relatively large euhedral zircons, with well-defined oscillatory zoning, yielded very old ${ }^{207} \mathrm{~Pb} /{ }^{206} \mathrm{~Pb}$ ages $(>3400 \mathrm{Ma}$ ). This population is low in common $\mathrm{Pb}$ and has $\mathrm{Th} / \mathrm{U}$ ratios between 0.3 and 0.8 (Table 1 ). The two oldest grains yielded an ${ }^{207} \mathrm{~Pb} /{ }^{206} \mathrm{~Pb}$ weighted mean age of $3471 \pm 3 \mathrm{Ma}$, whereas one grain (\#13) gave a concordant age of $3432 \pm 10 \mathrm{Ma}(2 \sigma)$, similar, within error, to the age of the Theespruit Pluton ( $3437 \pm 6 \mathrm{Ma}$ ) determined by Armstrong et al. (1990) from a sample taken a few hundred meters north of the GG-1 locality (Fig. 4a). The rims of these grains yield younger ${ }^{207} \mathrm{~Pb} /{ }^{206} \mathrm{~Pb}$ ages and lower Th/U ratios (<0.1) than the cores (Fig. 7a; Table 1) suggestive of metamorphic overgrowths, but discordance makes age determination difficult.

Zircons in the second population are characterized by bright, oscillatory zoning, probably of magmatic origin, and much lower $\mathrm{Th} / \mathrm{U}$ ratios $(0.2-0.01)$ than the first population. The seven most 
(a)
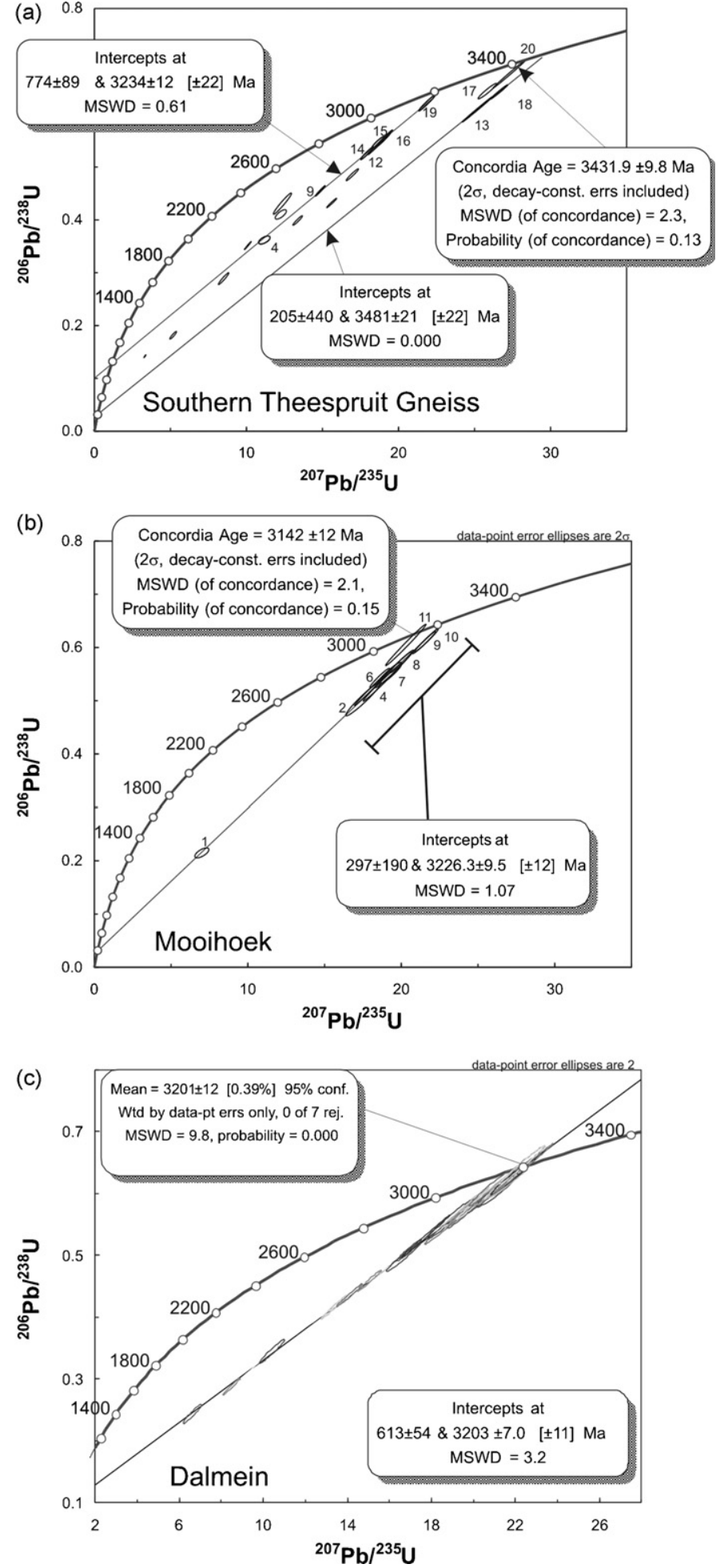

Fig. 7. U-Pb Concordia diagrams for the zircons populations in the (a) Southern Theespruit gneiss and (b) Mooihoek banded gneiss. Errors are at the $2 \sigma$ level. (c) $\mathrm{U}-\mathrm{Pb}$ Concordia diagrams for the zircons populations in the Dalmein sample (DL). Errors are at the $2 \sigma$ level.

concordant analyses from this population form a linear array that intercepts the concordia curve at $3234 \pm 12 \mathrm{Ma}(\mathrm{MSWD}=0.61 ; 2 \sigma)$ (Fig. 7a), an age that is identical within error to the crystallization age of the $3236 \pm 1$ Ma Nelsooghte pluton to the north of the Barberton greenstone belt (De Ronde and Kamo, 2000; Schoene et al., 2008), suggesting that the southern Theespruit gneiss was emplaced at the same time as the Nelsooghte pluton.

\subsection{Mooihoek gneiss (SG-1)}

The sample of the Mooihoek granodiorite (SG-1) was collected ca. $50 \mathrm{~m}$ from the contact with the Dalmein pluton $\left(26^{\circ} 07^{\prime} 01^{\prime \prime} \mathrm{S}-30^{\circ} 52^{\prime} 31^{\prime \prime} \mathrm{E}\right)$ (Fig. 4a). Although mineralogically similar to sample GG-1 of the Theespruit gneiss, this sample is distinguished by alternating bands of biotite- and plagioclase. Zircons from this sample are of magmatic origin, with dominantly euhedral to subhedral shapes, oscillatory zoning (ES-1), and Th/U ratios between 0.3 and 1.0 (Table 1 ). Many grains also preserve core structures that are particularly bright relative to the surrounding rims (ES-1). However, the cores were not discernibly older or chemically distinct from the rims.

Seven analyses from grain cores (points 2, 4, 5, 7, 8, 9, 10, 11) define a linear array with an upper intercept at $3226 \pm 9 \mathrm{Ma}$ (MSWD = 1.07) (Fig. 7b). One bright, prismatic, homogeneous zircon forms an outlier to this main population, with younger ${ }^{207} \mathrm{~Pb} /{ }^{206} \mathrm{~Pb}$ ages and enrichment in Th and $U$ (Table 1 ). The younger age recorded by this grain, together with extremely low Th/U ratios $(<0.01)$ suggests that it grew during a subsequent metamorphic event, although the age is poorly constrained. We consider that $3226 \pm 9 \mathrm{Ma}$ is the crystallization age of the Mooihoek gneiss, in good agreement with ages of other trondhjemites emplaced around the margins of the greenstone belt (e.g., $3227 \pm 1$ Ma Kaap Valley; Kamo and Davis, 1994) as well as with the porphyritic rocks of the Usutu suite exposed in the eastern margin of the greenstone Belt (Schoene and Bowring, 2010). Notably, greenstone remnants around the Stolzburg pluton yielded a number of metamorphic zircons (with $\mathrm{Th} / \mathrm{U}<0.2$ ), which gave a similar age of $3227 \pm 7$ Ma for metamorphism (Dziggel et al., 2005), suggesting that the emplacement of the Mooihoek gneiss took place during a time regional deformation and amphibolite-facies metamorphism.

\subsection{The Dalmein pluton (DL)}

Sample DL is from a K-feldspar megacrystic quartz-monzonite from the central part of the pluton $\left(26^{\circ} 06^{\prime} 15^{\prime \prime} \mathrm{S}-30^{\circ} 55^{\prime} 05^{\prime \prime} \mathrm{E}\right)$ (Fig. 4a). The zircons vary in brightness and shape and contain cores and darker rims (ES-1). Both cores and rims group have the same age and compositions, although the cores have suffered less $\mathrm{Pb}$ loss. Thirty-two point analyses from the different zircon grains vary from concordant to strongly discordant. They plot around a line that intersects upper Concordia at $3199 \pm 12 \mathrm{Ma}(2 \sigma ; \mathrm{MSWD}=8.1)$. Although several attempts to eliminate scatter around the $\mathrm{Pb}$ loss chord has been made, all points were considered to be representative of one ${ }^{207} \mathrm{~Pb} /{ }^{206} \mathrm{~Pb}$ age group - the large uncertainty to this age relates to six points $(4,6,9,8,15,24)$ that plot slightly above and below the regression line. A similar, albeit more precise, upper intercept age of $3203 \pm 7 \mathrm{Ma}(\mathrm{MSWD}=3.2)$ is indicated by 26 points that plot directly on the discordia line (Fig. 7c). This age is consistent with a ${ }^{207} \mathrm{~Pb} /{ }^{206} \mathrm{~Pb}$ weighted mean of $3201 \pm 12 \mathrm{Ma}$ defined by the seven most concordant points (discordance $<0.05$ ) and is here interpreted as the best estimate for the crystallization age for the Dalmein pluton.

\section{Discussion}

The Southern Theespruit and Mooihoek gneisses (Fig. 4a) record a structural and magmatic evolution akin to most gneiss domes in the southern Barberton terrane (e.g., Kisters and Anhaeusser, 1995; Kisters et al., 2003; Diener et al., 2005; Lana et al., 2010). The Southern Theespruit gneiss crystallized at $3234 \pm 12 \mathrm{Ma}$, contemporaneously with the $3236 \pm 1 \mathrm{Ma}$ (Schoene et al., 2008) Nelsooghte TTG pluton in the northern terrane. This was followed shortly by a second TTG magmatic pulse that led to the emplacement of various 
TTG bodies including the $3226 \pm 9$ Ma Mooihoek gneiss (Fig. 7b), the $3229.8 \pm 0.6 \mathrm{Ma}$ (Schoene et al., 2008) Vlakplaats granodiorite in the southern terrane, and the regionally extensive $3227 \pm 1 \mathrm{Ma}$ (Kamo and Davis, 1994) Kaap Valley pluton in the northern terrane.

The main fabric forming event in the high-grade gneisses of the southern Barberton terrane occurred at peak metamorphic conditions and was contemporaneous with the emplacement of the numerous granodiorite-granite sheets, which includes not only the $3226 \pm 9$ Ma Mooihoek gneiss to the south of the Dalmein (Fig. 5d and e), but also $3229 \pm 5 \mathrm{Ma}$ and $3212 \pm 1 \mathrm{Ma}$ syn kinematic dikes in the central Stolzburg complex (Dziggel et al., 2005; Schoene et al., 2008) and $3223 \pm 2$ Ma granodiorite dikes and syn kinematic granodiorites - eastern margin of the greenstone belt (Schoene et al., 2008; Schoene and Bowring, 2010). A mid-crustal depth of exhumation for the Mooihoek and Southern Theespruit bodies is indicated by the solid-state deformation and amphibolite-facies metamorphism, typified by the Stolzburg complex (Dziggel et al., 2005; Schoene et al., 2008), Theespruit complex (Diener et al., 2005) and Steynsdorp complex (Schoene et al., 2008; Lana et al., 2010).

By the time of intrusion of the Dalmein pluton, tectonomagmatic activity in the southern parts of the Barberton belt had largely ceased (Fig. 4). The Dalmein pluton was emplaced at higher crustal levels, since the pluton itself is undeformed and sharply truncates the low-grade structures in the greenstone belt (e.g., Kromberg structure). This field observation is at odds with the previously reported age of $3216 \pm 2$ Ma for the Dalmein pluton, based on analysis of two fractions of titanite and one discordant analysis of zircon (Kamo and Davis; 1994), taken from a sample collected near the contact with the Theespruit Formation. However, four lines of evidence suggest that the $3216 \pm 2 \mathrm{Ma}$ age for the Dalmein is artifically old, and reflects the presence of xenocrystic, inherited material. First, the contact between the younger Dalmein intrusion sharply crosscuts the Mooihoek Gneiss and establishes the possibility of inheritance. Second, the Dalmein pluton is characterized by millimeter- to meter-sized xenoliths of country rock (Fig. 6a-c), consistent with the presence of xenocrysts. Third, a number of rocks surrounding the pluton contain zircons and titanites ranging in age from 3230 to $3200 \mathrm{Ma}$, including the Doornhoek pluton (Kamo and Davis, 1994), the Theespruit Formation amphibolites (Kisters et al., 2003; Diener et al., 2005), the Stolzburg pluton (Kamo and Davis, 1994; Schoene et al., 2008), and the Mooihoek and Southern Theespruit gneisses (this study). Finally, though the use of titanite as a thermochronometer in metamorphic rocks is well-established, there are numerous examples of inherited titanite in granitic magmas (Zhang and Schärer, 1996; Pidgeon et al., 1996; Aleinikoff et al., 1995; Corfu, 1996; Corfu and Stone, 1998; Aleinikoff et al., 2002; Jung and Hellebrand, 2007). The blocking temperature of titanite for slowly-cooled metamorphic provinces is considered to be between $600^{\circ} \mathrm{C}$ (Mezger et al., 1991) and $700^{\circ} \mathrm{C}$ (Scott and St-Onge, 1995 ; Bingen and van Breemen, 1998), but the actual blocking temperature for individual grains will reflect the cooling rate (Dodson, 1973), as well as the grain size of the analysed material (Cherniak, 1993; Frost et al., 2000). Given the fast-cooling expected for the high crustal level emplacement of the Dalmein pluton, and that the $>0.180 \mathrm{mg}$ titanite fractions analysed by Kamo and Davis (1994) were fragments of much larger grains, we consider that titanite in Dalmein pluton has a high probability of preserving inherited ages.

We note that the older age assignment underpins recent tectonic models that emphasize an exceedingly fast transition (15 Ma) from collisional to extensional tectonics (Kisters et al., 2003; Diener et al., 2005). The younger age we report here suggests a more moderate pace of tectonic events with orogenic collapse now constrained to have occurred ca. $30 \mathrm{Ma}$ after crustal thickening. This lengthened timescale demonstrates that orogenic processes operative during the Phanerozoic (e.g., Caby et al., 2001, Whitney et al., 2003, Bonamici and Duebendorfer, 2009) is obtained also for early-middle Archean times.

\subsection{Timing constraints on the dome-and-keel structure}

Structural studies in the Barberton granite-greenstone belt (Williams and Furnell, 1979; De Wit, 1983; Jackson and Robertson, 1983; De Ronde and De Wit, 1994; Lowe et al., 1999; Westraat et al., 2005; Belcher and Kisters, 2006) emphasize the role of NW-SE-directed crustal shortening that followed the D2 collisional event at $3230 \mathrm{Ma}$ (e.g., Fig. 3). Shortening affected all stratigraphic units in the greenstone belt, from the upper Onverwacht volcanic sequences to the Moodies Group sediments, refolding the strata along NE-SW trending folds (Fig. 2). Within the same time frame, the Barberton belt witnessed the exhumation of high-grade rocks in the southern granitoid-gneiss terrane (e.g., the Theespruit Formation and the underlying Steynsdorp, Theespruit and Stolzburg domes; Fig. 1) from crustal depths of 25 and $35 \mathrm{~km}$ (Fig. 8a and b). The domes themselves have been shown to be part of a high-grade metamorphic core-complex zone (Kisters et al., 2003; Diener et al., 2005; Lana et al., 2010), which also include the Southern Theespruit Gneiss.

Exhumation of these rocks generated structural elements that are co-planar/co-linear with the NE-trending structural grain in the main greenstone belt (Fig. 2). For instance, strain in the Steynsdorp area (Figs. 2 and 4a) caused folding of the granitoid-greenstone contact into a NE-plunging conical fold, which is co-planar with the Steynsdorp and Kromberg fold structures in the main greenstone belt (e.g., Kisters and Anhaeusser, 1995; Lana et al., 2010). Smallscale folds in the Theespruit Formation (Kisters et al., 2003) are

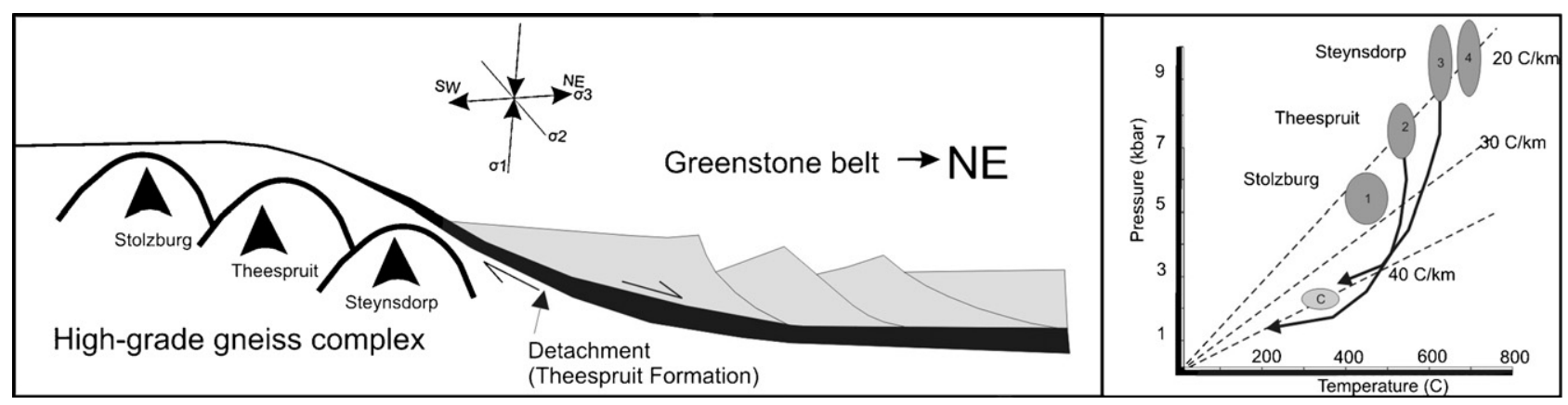

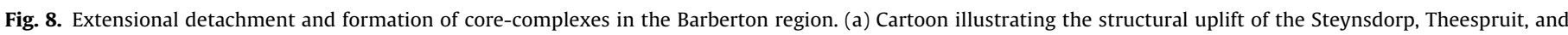

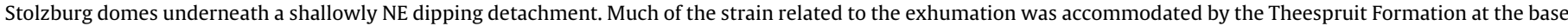

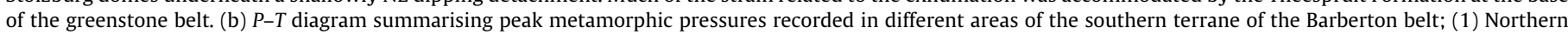

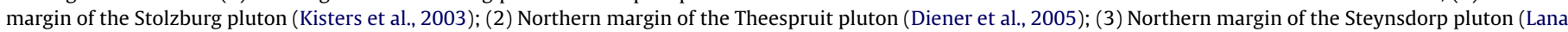
et al., 2010); (4) Southern margin of the Stolzburg pluton (Dziggel et al., 2002); (5) Onverwacht rocks to the north of the Theespruit Pluton (Cloete, 1991). 
coaxial with NE-plunging folds in the Moodies Group and Fig Tree Group (Jackson and Robertson, 1983), and correspond to the unidirectional NE plunge of the $\mathrm{L} 1$ lineation in the high-grade gneisses (Fig. 2). Similarly, the isoclinal symmetrical folds, NE-plunging (L1) mineral lineation, and layer-parallel boudins observed in the Southern Theespruit and Mooihoek gneisses (Fig. 4a) display the same geometry to those folds and boudins in the Steynsdorp and Stolzburg plutons (Fig. 2) (e.g., Diener et al., 2005; Lana et al., 2010).

These regional constraints and our present structural/ geochronological data suggest that the Southern Theespruit and Mooihoek gneisses were part of the younger TTG rocks emplaced between 3236 and $3227 \mathrm{Ma}$, and subsequently exhumed relative to the main greenstone belt as a consequence of late-D2 orogenic collapse. Peak metamorphism at ca. $3230 \mathrm{Ma}$ (Dziggel et al., 2005) coincided with the onset of exhumation of the high-grade gneisses. Thermochronological data available for the kilometerscale TTG plutons (see Schoene et al., 2008) are consistent with a long period of extensional unroofing and slow cooling of the gneiss domes around the greenstone belt in the wake of the ca. $3230 \mathrm{Ma}$ metamorphism. This is particularly true for several granitoid plutons in the northern and southern terranes (e.g., Vlakplaats intrusive, Nelsooghte and Kaap Valley plutons, Fig. 2) that record hornblende and apatite ages consistent with cooling below $400{ }^{\circ} \mathrm{C}$ between 3225 and $3180 \mathrm{Ma}$ (Layer et al., 1992, 1998; Schoene et al., 2008).

Much of the crust should have been exhumed before the emplacement of the Dalmein pluton at ca 3203 Ma. The Dalmein is a post-tectonic pluton that crosscuts not only the Kromberg structure, but also the limbs of the Steynsdorp and Onverwacht anticlines (Fig. 2) (Anhaeusser et al., 1981; Robb et al., 1983; De Wit, 1983). It therefore post-dates all the kilometer-scale folds in the greenstone belt, including the deformed Moodies Group, which is folded near the Steynsdorp dome and in the Eureka syncline (e.g., Jackson and Robertson, 1983; Lowe et al., 1999; Lowe and Byerly, 1999). Further south, the Dalmein truncates the NE-plunging tight folds in the Southern Theespruit and Mooihoek gneisses. It is thus reasonable that the main phase of kilometer-scale folding in the southern parts of the Barberton granite-greenstone belt, and the extension + cooling of the Meso-Archean crust, should be bracketed between the peak metamorphism at $3230 \mathrm{Ma}$ and the emplacement of the Dalmein Pluton at $3203 \pm 7$ Ma. The relatively low metamorphic pressures recorded in the greenstone belt to the north of the Dalmein contact zone (Fig. 8b) (260 MPa, Cloete, 1991) indicate emplacement at relatively shallow levels $(<11 \mathrm{~km})$. Thus, the high-grade southern Barberton gneisses, which record low geothermal gradients $\left(\sim 20^{\circ} \mathrm{C} / \mathrm{km}\right.$; Fig. 8b), must have been cooler than $300^{\circ} \mathrm{C}$ at ca. $3203 \mathrm{Ma}$, the time of the Dalmein intrusion. The $\mathrm{Ar} / \mathrm{Ar}$ hornblende and apatite age data available for the Kaap Valley and Nelshoogte and Steynsdorp domes (Layer et al., 1992, 1998; Schoene et al., 2008), and the structural and metamorphic features in the high-grade gneisses do not support a regional high temperature $\left(>500^{\circ} \mathrm{C}\right)$ thermal overprint during the D3 event. Much of the deformation and thermal overprint related to D3 was largely confined to the margins of the kilometer-scale potassic batholiths such as the Heereveen, Mpuluzi and Pigg's peak Batholiths in the south (Belcher and Kisters, 2006; Schoene et al., 2008).

We thus propose that much of the present-day dome-andkeel structure of the Barberton greenstone belt resulted from a ca. 30 million year period of NE-SW extension of relatively hot $\left(>500^{\circ} \mathrm{C}\right)$ crust mid- to lower-crustal gneisses and concomitant TTG plutonism. The orthogonal strain partitioning that we infer, i.e., NEextension in the lower to mid-crust and NW-SE compression in the upper crustal rocks, lends support to the crustal-scale chocolatetablet boudinage model proposed for other Archean provinces. These models link extension/exhumation in the lower crust with contemporaneous shortening in the upper crust, commonly envi- sioned as infolding of supracrustal rocks between rising domes of hot, mid-crustal basement (Marshak et al., 1992, 1997; Alkmin and Marshak, 1998; Marshak, 1999; Tohver et al., 2006, 2007). The thermal component necessary to weaken the lower- and mid-crust for this "regional boudinage" may be directly related to the high-grade metamorphism and voluminous TTG magmatism, since both processes are spatially and temporally linked to the D2 event (e.g., Kisters et al., 2003).

\section{Acknowledgements}

This material is based upon work supported by the National Research Foundation under grant number NRF2050238 via Alex Kisters. We would like to thank all farmers and land owners in the Badplaats areas for their hospitality and granting access to their lands. Cristiano Lana acknowledges funding from the Claude Leon Foundation. The SHRIMP II at the John deLaeter Centre is operated by a consortium consisting of Curtin University, the Geological Survey of Western Australia and the University of Western Australia. E. Tohver acknowledges funding from the University of Western Australia. We sincerely appreciate reviews by Randall Parish, Schoene Blair and two anonymous referees. We also thanks Alex Kisters for comments on an earlier version of this manuscript.

\section{Appendix A. Supplementary data}

Supplementary data associated with this article can be found, in the online version, at doi:10.1016/j.precamres.2009.12.001.

\section{References}

Aleinikoff, J.N., Zartman, R., Walter, M., Rankin, D., Lyttle, P.T., Burton, W., 1995. U-Pb ages of metarhyolites of the Catoctin and Mount Rogers Formations, central and southern Appalachians: evidence for two pulses of Iapetan rifting. American Journal of Sciences 295, 428-454.

Aleinikoff, J.N., Wintsch, R.P., Fanning, M., Dorais, M.J., 2002. U-Pb geochronology of zircon and polygenetic titanite from the Glastonbury Complex, Connecticut, USA: an integrated SEM, EMPA, TIMS, and SHRIMP study. Chemical Geology 188, $125-147$.

Alkmin, F.F., Marshak, S., 1998. Transamazonian orogeny in the southern São Francisco Craton region, Minas Gerais, Brazil: evidence for Paleoproterozoic collision and collapse in the Quadrilátero Ferriífero. Precambrian Research 90, 29-58.

Anhaeusser, C.R., 1969. The stratigraphy, structure and gold mineralization of the Jamestown and Sheba Hills area of the Barberton Mountain land. Ph.D. Thesis, University of the Witwatersrand, Johannesburg, South Africa, 322 pp.

Anhaeusser, C.R., 1984. Structural elements of Archean granite-greenstone terranes as exemplified by the Barberton Mountain Land, South Africa. In: Kroener, A., Greiling, R. (Eds.), Precambrian Tectonics Illustrated. E. Schweizerbartsche Verlagsbuchhandlung, Stuttgart, Germany, $419 \mathrm{pp}$.

Anhaeusser, C.R., 2001. The anatomy of an extrusive-intrusive Archean maficultramafic sequence: the Nelshoogte Schist Belt and Stolzburg Layered Ultramafic Complex, Barberton Greenstone Belt, South Africa. South African Journal of Geology 104, 167-204.

Anhaeusser, C.R., Robb, L.J., Viljoen, M.J., 1981. Provisional Geological Map of the Barberton Greenstone Belt and Surrounding Terrane, Eastern Transvaal and Swaziland Geological Society of South Africa, Johannesburg, Scale 1:250,000.

Armstrong, R.A., Compston, W., deWit, M.J., Williams, I.S., 1990. The stratigraphy of the 3.5-3.2 Ga Barberton Greenstone Belt revisited: a single zircon ion microprobe study. Earth and Planetary Sciences Letters 101, 90-106.

Belcher, R.W., Kisters, A.F.M., 2006. Syntectonic emplacement and deformation of the Heerenveen batholith: conjectures on the tectonic setting of the 3.1 Ga granite magmatism in the Barberton granite-greenstone terrane, South Africa. In: Reimold, U., Gibson, R. (Eds.), Processes in the Early Earth. Geological Society of America Special Paper, vol. 405, pp. 211-232.

Bingen, B., van Breemen, O., 1998. U-Pb monazite ages in amphibolite- to granulite-facies orthogneiss refl ect hydrous mineral breakdown reactions: Sveconorwegian Province of SW Norway. Contributions to Mineralogy and Petrology 132, 336-353, doi:10.1007/s004100050428.

Byerly, G.R., Kröner, A., Lowe, D.R., Todt, W., Walsh, M.M., 1996. Prolonged magmatism and time sontraints for sediment deposition in the early Archean Barberton greenstone belt: evidence from the Upper Onverwacht and Fig Tree Groups. Precambrian Research 78, 125-138.

Bonamici, C.E., Duebendorfer, E.M., 2009. Gravitational collapse of a Paleopro terozoic orogen, southern Hualapai Mountains, Arizona. Precambrian Research 175, 35-50. 
Caby, R., Hammor, D., Delor, C., 2001. Metamorphic evolution, partial melting and Miocene exhumation of lower crust in the Edough metamorphic core complex, west Mediterranean orogen, eastern Algeria. Tectonophysics 342, 239-273.

Cherniak, D.J., 1993. Lead diffusion in titanite and preliminary results on the effects of radiation damage on Pb transport. Chemical Geology 110, 177-194.

Cloete, M., 1991. An overview of metamorphism in the Barberton greenstone belt. In: Ashwal, L.D. (Ed.), Two Cratons and an Orogen-Excursion Guidebook and Review Articles for a Field Workshop Through Selected Archean Terranes of Swazioland, South Africa and Zimbabwe: IGCP project 280. Department of Geology, University of Witwatersrand, Johannesburg, pp. 85-98.

Corfu, F., 1996. Multistage zircon and titanite growth and inheritance in an Archean gneiss complex, Winnipeg River Subprovince, Ontario. Earth and Planetary Science Letters $141,175-186$.

Corfu, F., Stone, D., 1998. The significance of titanite and apatite U-Pb ages: constraints for the post-magmatic thermal-hydrothermal evolution of a batholithic complex, Berens River area, northwestern Superior Province, Canada. Geochimica et Cosmochimica Acta 62, 2979-2995.

De Ronde, C.E.J., De Wit, M.J., 1994. Tectonic history of the Barberton greenstone belt, South Africa: 490 million years of Archean crustal evolution. Tectonics 13, 983-1015.

De Ronde, C.E.J., Kamo, S.L., 2000. An Archean arc-arc collisional event: a short-lived (ca. 3 Myr) episode, Weltevreden area, Barberton greenstone belt, South Africa. Journal of African Earth Sciences 30, 219-248.

De Wit, M.J., 1983. Notes on a preliminary 1:25,000 geological map of the southern part of the Barberton greenstone belt. In: Anhaeusser, C.R. (Ed.), Contributions to the Geology of the Barberton Mountain Land. Geological Society of South Africa Special Publication 9, pp. 185-187.

De Wit, M.J., 1998. On Archean granites, greenstones, cratons and tectonics: does the evidence demand a verdict? Precambrian Research 91, 181-226.

De Wit, M.J., Roering, C., Hart, R.J., Armstrong, R.A., De Ronde, C.E.J., Green, R.W.E., Tredoux, M., Peberdy, E., Hart, R.A., 1992. Formation of an Archean continent. Nature 357, 553-562.

Diener, J.F.A., Stevens, G., Kisters, A.F.M., Poujol, M., 2005. Geotectonic evolution of the Tjakastad Schist belt, Barberton greenstone belt, South Africa: a record of mid-Archean metamorphism and terrain exhumation. Precambrian Research $143,87-112$.

Dodson, M.H., 1973. Closure temperature in cooling geochronological and petrological systems. Contributions to Mineralogy and Petrology 40, 259274.

Dziggel, A., Stevens, G., Poujol, M., Anhaeusser, C.R., Armstrong, R.A., 2002. Metamorphism of the Granite-Greenstone terrane south of the Barberton greenstone belt, South Africa: an insight into the tectono-thermal evolution of the lower portions of the Onverwacht Group. Precambrian Research 114, 221-247.

Dziggel, A., Armstrong, R.A., Stevens, G., Nasdala, L., 2005. Growth of zircon and titanite during metamorphism in the granitoid-gneiss terrane south of the Barberton greenstone belt, South Africa. Mineralogical Magazine 69, 1021-1038.

Dziggel, A., Knipfer, S., Kisters, A.F.M., Meyer, F.M., 2006. P-T and structural evolution during exhumation of high- $T$, medium- $P$ basement rocks in the Barberton Mountain Land. Journal of Metamorphic Geology 24, 535-551.

Eriksson, K.A, 1979. Marginal marine depositional processes from the Archean Moodies Group, Barberton Mountain Land, South Africa: evidence and significance. Precambrian Research 8, 153-182.

Frost, R.B., Chamberlain, K., Schumacher, J., 2000. Sphene (titanite): phase relations and role as a geochronometer. Chemical Geology 172, 131-148.

Heubeck, C., Lowe, D.R., 1994. Late syndepositional deformation and detachment tectonics in the Barberton greenstone belt, South Africa. Tectonics 13, 1514-1536.

Jung, S., Hellebrand, E., 2007. Textural, geochronological and chemical constraints from polygenetic titanite and monogenetic apatite from a mid-crustal shear zone: an integrated EPMA, SIMS, and TIMS study. Chemical Geology 241, 88-107.

Jackson, M.P.A., Robertson, D.I., 1983. Regional implications of early-Precambrian strains in the Onverwacht Group adjacent to the Lochiel Granite, northwest Swaziland. In: Anhaeusser, C.R. (Ed.), Contributions to the Geology of the Barberton Mountain Land. Geological Society of South Africa, Special Publication 9, 45-62.

Kamo, S.L., Davis, D.W., 1994. Reassessment of Archean crustal development in the Barberton Mountain Land, South Africa, based on $\mathrm{U}-\mathrm{Pb}$ dating. Tectonics 13, 167-192.

Kisters, A.F.M., Anhaeusser, C.R., 1995. Emplacement features of Archean TTG plutons along the southern margin of the Barberton greenstone belt, South Africa. Precambrian Research 75, 1-15.

Kisters, A.F.M., Stevens, G., Dziggel, A., Armstrong, R.A., 2003. Extensional detachment faulting at the base of the Barberton greenstone belt: evidence for a $3.2 \mathrm{Ga}$ orogenic collapse. Precambrian Research 127, 355-378.

Kohler, E., Anhaeusser, C.R., 2002. Geology and geodynamic setting of Archean silicic metavolcaniclastic rocks of the Bien Venue Formation, Fig Tree Group, northeast Barberton greenstone belt, South Africa. Precambrian Research 116 199-235.

Kroner, A., Compston, W., William, I.S., 1989. Growth of early Archean crust in the Ancient Gneiss Complex of Swaziland as revealed by single zircon dating. Tectonophysics 161, 271-298, doi:10.1016/0040-1951(89)90159-5.

Kröner, A., Byerly, G.R., Lowe, D.R., 1991. Chronology of early Archean granitegreenstone evolution in the Barberton mountain land, South Africa, based on precise dating by single zircon evaporation. Earth and Planetary Sciences Letters 103, 41-54.
Kröner, A., Hegner, E., Wendt, J.I., Byerly, G.R., 1996. The oldest part of the Barberton granitoid-greenstone terrain, South Africa, evidence for crust formation between 3.5 and 3.7 Ga. Precambrian Research 78, 105-124.

Lamb, S., 1987. Archean synsedimentary tectonic deformation-a comparison with the Quaternary. Geology 15, 565-568.

Lambert, R., 1976. Archean thermal regimes, crustal and upper mantle temperatures and a progressive evolutionary model for the earth. In: Windley, B.F. (Ed.), The Early History of the Earth. Wiley and Sons, New York, pp. 363-376.

Lana, C., Kisters, A., Stevens, G., 2010. Exhumation of MesoArchean TTG gneisses from the middle crust: insights from the Steynsdorp core complex, Barberton granitoid-greenstone terrain, South Africa. Geological Society of America Bulletin 122, 183-197.

Layer, P.W., Kröner, A., York, D., 1992. Pre-3000 Ma thermal history of the Archean Kaap Valley pluton, South Africa. Geology 20, 717-720.

Layer, P.W., Lopez-Martinez, M., Kröner, A., York, D., McWilliams, M., 1998. Thermochronometry and paleomagnetism of the Archean Nelshoogte Pluton, South Africa. Geophysical Journal International 135, 129-145.

Lowe, D.R., 1994. Accretionary history of the Archean Barberton Greenstone Belt (3.55-3.22 Ga), southern Africa. Geology 22, 1099-1102.

Lowe, D.R., 1999. Geologic evolution of the Barberton Greenstone Belt and vicinity. In: Lowe, D.R., Byerly, G.R. (Eds.), Geologic Evolution of the Barberton Greenstone Belt, South Africa. Geological Society of America Special Paper 329, 287-312.

Lowe, D.R., Byerly, G.R., 1999. Stratigraphy of the west-central part of the Berberton Greenstone Belt, South Africa. In: Lowe, D.R., Byerly, G.R. (Eds.), Geologic Evolution of the Barberton Greenstone Belt, South Africa. Geological Society of America Special Paper 329, 1-36.

Lowe, D.R., Byerly, G.R., 2007. An overview of the geology of the Barberton greenstone belt: implications for early crustal development. In: van Kranendonk, M.J., et al. (Eds.), Developments in Precambrian Geology, vol. 15, pp. 481526.

Lowe, D. R., Byerly, G.R., Heubeck, C., 1999. Structural divisions and development of the west-central part of the Barberton Greenstone Belt. In: Lowe, D.R., Byerly G.R. (Eds.), Geologic Evolution of the Barberton Greenstone Belt, South Africa. Geological Society of America Special Paper 329, 83-114.

Marshak, S., 1999. Deformation style way back when: thoughts on the contrasts between Archean/Paleoproterozoic and contemporary orogens. Journal of Structural Geology 21, 1175-1182.

Marshak, S., Alkmim, F., Jordt-Evangelista, H., 1992. Proterozoic crustal extension and the generation of dome-and-keel structures in an Archean granitegreenstone terrane. Nature 357, 491-493.

Marshak, S., Tinkham, D., Alkmim, F., Brueckner, Bornhorst, T., 1997. Dome-and-keel provinces formed during Paleoproterozoic orogenic collapse-core complexes, diapirs, or neither? Examples from the Quadrilatero Ferrifero and the Penokean orogen. Geology 25, 415-418.

Mezger, K., Rawnsley, C.M., Bohlen, S.R., Hanson, G.N., 1991. U-Pb garnet, titanite monazite, and rutile ages: implications for the duration of high-grade metamorphism and cooling histories, Adirondack Mountains, New York. The Journal of Geology 99, 415-428.

Moyen, J.F.M., Stevens, G., Kisters, A.F.M., 2006. Record of mid-Archean subduction from metamorphism in the Barberton terrain, South Africa. Nature 442, 559-562.

Nelson, D.R., 1997. Compilation of SHRIMP U-Pb Zircon Geochronology Data, 1996 GSWA, Record 1997/2, 189 pp.

Pidgeon, R.T., Bosch, D., Bruguier, O., 1996. Inherited zircon and titanite U-Pb systems in an Archean syenite from southwestern Australia: implications for U-Pb stability of titanite. Earth and Planetary Science Letters 141, 187198.

Robb, L.J., Anhaeusser, C.R., Van Nierop, D.A., 1983. The recognition of the Nelspruit batholith north of the Barberton greenstone belt and its significance in terms of Archean crustal evolution. In: Anhaeusser, C.R. (Ed.), Contributions to the Geology of the Barberton Mountain Land. Special Publication of the Geological Society of South Africa 9, 117-130.

Schoene, B., Bowring, S.A., 2007. Determining accurate temperature-time paths from $\mathrm{U}-\mathrm{Pb}$ thermochronology: an example from the SE Kaapvaal Craton, Southern Africa. Geochimica et Cosmochimica Acta 71, 165-185.

Schoene, B., De, Wit., Bowring, S.A., 2008. MesoArchean assembly and stabilization of the eastern Kaapvaal craton: a structural-thermochronological perspective. Tectonics 27, 1-27.

Schoene, B., Duda, F.O., De Wit, M.J., Bowring, S.A., 2009. Sm-Nd isotopic mapping of lithospheric growth and stabilization in the eastern Kaapvaal craton. Terra Nova 21, 219-228.

Schoene, B., Bowring, S.A., 2010. Rates and mechanisms of Mesoarchean magmatic arc construction, eastern Kaapvaal craton. Swaziland Geological Society of America Bulletin 122, 408-429.

Scott, D.J., St-Onge, M.R., 1995. Constraints on $\mathrm{Pb}$ closure temperature in titanite based on rocks from the Ungava Orogen, Canada: implications for $\mathrm{U}-\mathrm{Pb}$ geochronology and $P-T-t$ path determinations. Geology 23, 1123-1126.

Tohver, E., Teixeira, W., van der Pluijm, B.A., Geraldes, M.C., Bettencourt, J.S., Rizzotto, G., 2006. Restored transect across the exhumed Grenville orogen of Laurentia and Amazonia, with implications for crustal architecture. Geology 134, 669-672.

Tohver, E., Holm, D., van der Pluijm, B.A., Essene, E.J., Cambray, W.C., 2007. Penokean and Post-Penokean reactivation of the Great Lakes Tectonic Zone: thermochronology of shear zones in the Marquette region, northern Michigan, USA. Precambrian Research 157, 144-168. 
Van Kranendonk, M.J., Kröner, A., Hegner, E., Connelly, J., 2009. Age, lithology and structural evolution of the c. $3.53 \mathrm{Ga}$ Theespruit Formation in the Tjakastad area, southwestern Barberton Greenstone Belt, South Africa, with implications for Archean tectonics. Chemical Geology 261, 115-139.

Viljoen, M.J., Viljoen, R.P., 1969. An introduction to the geology of the Barberton granite-greenstone terrain. Special Publication of the Geological Society of South Africa 2, 9-28.

Visser, D.J.L., 1956. The Geology of the Barberton Area. S. Afr. Geol. Surv. Spec. Publ. 15,242 pp.

Westraat, J.D., Kisters, A.F.M., Poujol, M., Stevens, G., 2005. Transcurrent shearing, granite sheeting and the incremental construction of the tabular 3.1 Ga Mpuluzi batholith, Barberton granite-greenstone terrane, South Africa. Journal of the Geological Society of London 162, 373-388.
Whitney, D.L., Teyssier, C., Fayon, A.K., Hamilton, M.A., Heizler, M., 2003. Tectonic controls on metamorphism, partial melting, and intrusion: timing and duration of regional metamorphism and magmatism in the Nigde Massif, Turkey. Tectonophysics 376, 37-60.

Williams, D.A.C., Furnell, R.G., 1979. A reassessment of part of the Barberton area. Precambrian Research 9, 325-347.

Williams, I.S., 1998. U-Th-Pb geochronology by ion microprobe. In: McKibben, M.A. Shanks III, W.C., Ridley, W.I. (Eds.), Applications of Microanalytical Techniques to Understanding Mineralizing Processes. Reviews in Economic Geology 12, $1-35$.

Zhang, L.-S., Schärer, U., 1996. Inherited Pb components in magmatic titanite and their consequence for the interpretation of U-Pb ages. Earth and Planetary Science Letters 138, 57-65, doi:10.1016/0012-821X(95)00237-7. 